[Original]

\title{
Purification, Characterization and Biological Activities of a Garlic Oligosaccharide
}

\author{
Sadaji Tsukamoto ${ }^{1, *}$, Kouji OKamoto ${ }^{2,3}$, Junji Inanaga ${ }^{4}$ and Yuji Karasaki ${ }^{5, * *}$ \\ 'Department of Nutrition of Home Economics, Kyushu Women's University, Fukuoka 807-8586, \\ Japan \\ ${ }^{2}$ Graduate School of Life Science \& Systems Engineering, Kyushu Institute of Technology, Fukuoka \\ 808-0196, Japan \\ ${ }^{3}$ Department of Bioscience and Bioinformatics, Kyushu Institute of Technology, Fukuoka \\ 820-8502, Japan \\ ${ }^{4}$ Institute for Materials Chemistry and Engineering, Kyushu University, Fukuoka 812-8581, Japan \\ ${ }^{5}$ Department of Clinical Pathophysiology, School of Health Sciences, University of Occupational \\ and Environmental Health, Japan. Yahatanishi-ku, Kitakyushu 807-8555, Japan
}

\begin{abstract}
A novel oligosaccharide was purified from garlic (Allium sativum L.) bulbs via hot water extraction, ammonium sulfate precipitation, gel filtration and ion exchange chromatography. The molecular weight of the oligosaccharide was determined to be 1800 . A nuclear magnetic resonance (NMR) study showed that ten fructose molecules were connected by $\beta 1-2$ linkage to a terminal glucose. The oligosaccharide had cytotoxic activities against human malignant lymphoma cells (U937) and colon adenocarcinoma cells (WiDr) in vitro. Furthermore, this oligosaccharide significantly suppressed the growth of murine colon adenocarcinoma cells (colon 26) in vivo. The oligosaccharide also stimulated interferon- $\gamma$ production by human peripheral blood lymphocyte in vitro, indicating that it may activate the immunological pathways and suppress the growth of tumors in vivo.
\end{abstract}

Key words : garlic bulb, oligosaccharide, NMR, cytotoxic effect, immunological activity.

(Received 15 February 2008, accepted 17 April 2008)

* Corresponding author: Sadaji TsukAмото, 601-8-21 Katano 4-chome, Kokurakita-ku, Kitakyushu 802-0064 Japan, e-mail: kikumi@m8.dion.ne.jp, Phone: +81-93-922-7731, FAX: +81-93-922-7731

** Present address: Department of Human Information and Life Sciences,School of Health Sciences, University of Occupational and Environmental Health, Japan, Yahatanishi-ku, Kitakyushu, 807-8555, Japan 


\section{Introduction}

Garlic (Allium sativum L) bulbs are composed of $26 \sim 30 \%(\mathrm{w} / \mathrm{w})$ carbohydrates, which are the main ingredients aside from moisture. Garlic contains the polysaccharides fructan and galactan, and oligosaccharide scorodose [1]. An epidemiological research has indicated that garlic is an effective cancer-preventive food [2]. Organosulfur compounds in the garlic bulbs have been thought to be the main components as anti-tumor substances. For example, diallylsulfide and diallyldisulfide were shown to exert an anti-tumor activity [3]. Diallyltrisulfide had the same effect [4]. Moreover, allicin (diallyl thiosulfinate) was shown to be toxic in various mammalian cells in a dose-dependent manner in vitro [5]. Ajoene had an anti-tumor activity not only in vitro but also in vivo [6].

We have long been interested in a purified garlic lectin protein and reported its antitumor activity [7]. During the process of garlic lectin purification, we also prepared a garlic oligosaccharide. We report here the anti-growth effect of garlic oligosaccharide on tumor cells both in vitro and in vivo, and an immunological activity as well.

\section{Materials and Methods}

\section{Purification of garlic oligosaccharide}

We mixed $164 \mathrm{~g}$ of fresh garlic bulbs grown in Japan with $164 \mathrm{ml}$ of distilled water. They were then homogenized for $2 \mathrm{~min}$ at room temperature and heated for $30 \mathrm{~min}$ at $85^{\circ} \mathrm{C}$. The infusion was filtrated through gauze to remove insoluble materials. The crude extract was adjusted to $80 \%$ saturation with $\left(\mathrm{NH}_{4}\right)_{2} \mathrm{SO} 4$ maintained at $4^{\circ} \mathrm{C}$ for $30 \mathrm{~min}$, and centrifuged at $8000 \mathrm{rpm}$ for 10 min. The precipitate was resuspended in $30 \mathrm{ml}$ of $0.02 \mathrm{M}$ acetate buffer (pH5.0) and centrifuged at $8000 \mathrm{rpm}$ for $10 \mathrm{~min}$. The supernatant was applied to a Sephadex G-75 column $(4.5 \times 65 \mathrm{~cm})$, equilibrated with the $0.02 \mathrm{M}$ acetate buffer (pH5.0), and eluted with the same buffer. Aliquots of $15 \mathrm{ml}$ were collected, and the protein content in each fraction was measured by optical density at $280 \mathrm{~nm}$. To measure the sugar content of each fraction, $50 \mu \mathrm{l}$ was extracted and colored by the phenol sulfuric acid method and subsequently measured at $490 \mathrm{~nm}$. Three peaks were detected at $280 \mathrm{~nm}$; the second peak was the highest and contained sugar and it also contained lectin protein. The aliquots were concentrated by ultrafiltration using the AMICON YM10 membrane to $10 \mathrm{ml}$ and then applied to a DEAE-Toyopearl column $(3.2 \times 33 \mathrm{~cm})$, equilibrated with the 0.02 $\mathrm{M}$ phosphate buffer (pH6.0) and eluted with the same buffer by $\mathrm{NaCl}$ linear gradient $(0-0.25 \mathrm{M})$. The sugar fraction, the first peak, was eluted and then pooled. Thereafter it was dialyzed against water and freeze-dried.

\section{Measurement of molecular weight}

The molecular weight of the oligosaccharide was measured by gel filtration chromatography (GFC) using a Bio-Gel-P2 column (2.0×64.1 cm: Bio-Rad Laboratories). Glucose (MW=180.16), sucrose $(\mathrm{MW}=342.34)$, raffinose $(\mathrm{MW}=522.46)$, stachyose $(\mathrm{MW}=666.58)$ and maltohexase $(\mathrm{MW}=990.87)$ were employed as standard reference compounds, and distilled water was used as an eluent. 


\section{Structural analysis}

The matrix assisted laser-desorption ionization-time of flight (MALDI-TOF) mass spectrum was obtained with BIFLEX III (Bruker) using 2, dihydroxybenzoic acid as a matrix. 'H NMR and ${ }^{13} \mathrm{C}$ NMR spectra were measured on a Varian UNITY INOVA 500 spectrometer at $500 \mathrm{MHz}$ and $125 \mathrm{MHz}$, respectively.

Chemical shifts are given by relation to that of internal TSP-d4 $\left(\mathrm{Me}_{3} \mathrm{CD}_{2} \mathrm{CD}_{2} \mathrm{CO}_{2} \mathrm{Na}\right)$ in $\mathrm{D}_{2} \mathrm{O}$. Various techniques were examined, such as distortion enhancement by polarization transfer (DEPT), double quantum filtered correlation spectroscopy (DQF-COSY), total correlation spectroscopy (TOCSY), rotating frame overhauser enhancement spectroscopy (ROESY), heteronuclear single quantum coherence (HSQC) and heteronuclear multiple bond correlation (HMBC).

\section{Cell culture}

Human histiocytic lymphoma cells (U937) and human colon adenocarcinoma cells (WiDr) were offered by the Health Science Research Bank at Japan Health Foundation. Murine colon adenocarcinoma cells (Colon-26) were kindly supplied by Dr. T. Obata at Kanazawa University Cancer Research Institute. U937, WiDr and Colon-26 cells were cultured in RPMI 1640 medium supplemented with $10 \%$ fetal bovine serum (FBS), $100 \mu \mathrm{g} / \mathrm{ml}$ of streptomycin and $50 \mu \mathrm{g} / \mathrm{ml}$ of gentamicin sulfate in a humidified atmosphere of $5 \% \mathrm{CO}_{2}$ and $95 \%$ air at $37^{\circ} \mathrm{C}$. At subconfluence, WiDr cells were harvested by treating with $0.25 \%$ trypsin and $0.02 \%$ EDTA.

\section{Cell viability analysis (in vitro experiment)}

U937 $\left(1 \times 10^{4}\right.$ cells $)$ and WiDr $\left(5 \times 10^{3}\right.$ cells $)$ cells were cultured in flat-bottomed microtiter culture plat wells with or without several concentrations of garlic oligosaccharide in RPMI 1640 medium containing $10 \% \mathrm{FBS}$ at $37^{\circ} \mathrm{C}$ for the indicated days. U937 cells were harvested every day and viable cells were counted with a hemocytometer after staining with trypan blue [8]. Viable WiDr cells were determined after adding cell counting kit- 8 solution (Dojin Chemical Co. Ltd., Kumamoto, Japan) to each well of a microtiter plate containing the cells. The cells were incubated in a $\mathrm{CO}_{2}$ incubator for $3 \mathrm{~h}$, and then the absorbance of each well was measured by a microplate reader at $450 \mathrm{~nm}$.

\section{Animals}

Male BALB/cN Sea mice were obtained from Kyudo, Nakatsu, and maintained on the basal diet CE-II (CLEA Japan Inc., Tokyo, Japan) until use in the present experiment at age 8 weeks.

\section{Anti-tumor analysis in vivo experiment}

$\mathrm{BALB} / \mathrm{cN}$ Sea mice(body weight : $23-24 \mathrm{~g}$ ) were inoculated subcutaneously with $1 \times 10^{5}$ cells of murine colon adenocarcinoma (Colon 26) in $0.2 \mathrm{ml}$ of phosphate-buffered saline (PBS) on day 0 . The mice were given oral administration of oligosaccharide at a dose of $0.5 \mathrm{mg}$ and 10 $\mathrm{mg}$ in $0.5 \mathrm{ml}$ of PBS every other day from day 0 . Control mice received only a solvent (PBS). Each group consisted of 6 mice. The anti-tumor activity of oligosaccharide was evaluated by 
measuring tumor growth on days 19 and 22 after tumor inoculation and expressed as the ratio of tumor size of the oligosaccharide-treated mice to that of the control mice. Tumor size $\left(\mathrm{mm}^{3}\right)$ was measured with calipers and calculated using the following formula: Tumor size $\left(\mathrm{mm}^{3}\right)=$ [longest diameter $] \times[$ shortest diameter $] \times[$ shortest diameter $]$.

All experimental procedures were in accordance with the Kyushu Institute of Technology Animal Care and Use Regulations.

Assay of cytokine production stimulating activity of human peripheral blood lymphocytes (PBL)

PBLs were obtained from 6 healthy male humans via the centrifugation method. An assay of cytokine production stimulating activity was performed in a 96-well culture plate. Human PBLs were inoculated at $1 \times 10^{6}$ cells $/ \mathrm{ml}$ in an RPMI 1640 medium containing $0,0.1$ and $5 \mathrm{mg} / \mathrm{ml}$ of oligosaccharide. Following cultivation in a $\mathrm{CO}_{2}$ incubator at $37^{\circ} \mathrm{C}$, interferon- $\gamma$ concentrations in the culture medium were measured by the ELISA method. The study on this assay using blood samples was approved by the Ethical Committee of the SRL Inc., Tokyo, Japan.

\section{Results and Discussion}

\section{Structure elucidation}

GFC analysis suggested that the molecular weight of the oligosaccharide was ca. 1800 (Fig.1). This was supported by MALDI-TOF mass spectrum, as shown in Fig. 2. The typical-162 (fragment) peaks, which are accompanied by +18 (water molecule) peaks, indicated the existence of a regularly connected $\mathrm{C}_{6}$-monosaccharide unit resembling fructose. Actually, the NMR spectra (DEPT, HSQC, HMBC, and DQF-COSY) suggested that a $\beta 1-2$ fructan sequence with a glucose terminus would form the bulk of the oligosaccharide ( Fig.3). As can be seen from Table 1, the major peaks appeared in the ${ }^{1} \mathrm{H}$ and ${ }^{13} \mathrm{C}$ NMR spectra of the oligosaccharide and corresponded with those of commercial inulin $(\mathrm{n}=\mathrm{ca} .20 \sim 30)$.

\section{In vitro studies}

Figure $4 \mathrm{a}$ shows the dose-dependent effects of the garlic oligosaccharide on the growth of U937 and WiDr cells. After a $96 \mathrm{~h}$ treatment at a concentration of $5 \mathrm{mg} / \mathrm{ml}$, the viabilities of the U937 and WiDr cells were 31 and 20\%, respectively. The time-dependent effects of garlic oligosaccharide on the growth of U937 and WiDr cells are shown in Fig. 4b. It had quite a stronger cytotoxic effect on the WiDr cells by the $24 \mathrm{~h}$ and $48 \mathrm{~h}$ treatments compared to that of the U937 cells. We previously reported that a garlic lectin, which is purified with an oligosaccharide at the step of gel chromatography, exhibited strong anti-growth effects on these tumor cells [7], indicating that our purified products may be the major cancer-preventive components in the garlic bulbs besides the organosulfur compounds $[3-5]$.

\section{In vivo studies}

The effect of oligosaccharide on the growth of subcutaneously implanted Colon-26 cells in 


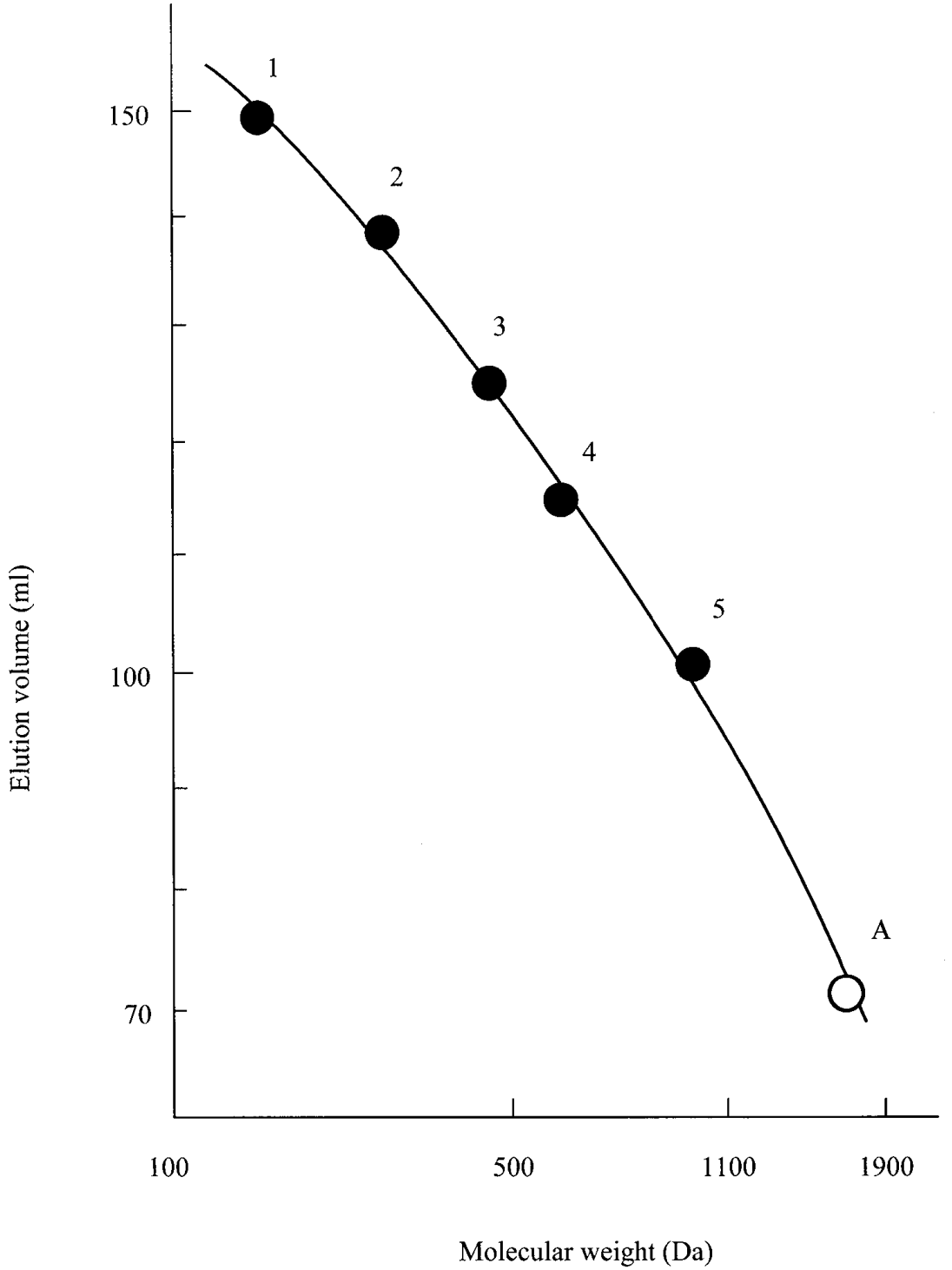

Fig. 1. Measurement of molecular weight.

The molecular weight of the oligosaccharide was measured by gel filtration chromatography (GFC) using a Bio-Gel-P2 column. 1 . Glucose $(\mathrm{MW}=180.16)$, 2. sucrose $(\mathrm{MW}=342.34), 3$. raffinose $(\mathrm{MW}=522.46)$, 4. stachyose $(\mathrm{MW}=666.58)$ and 5. maltohexase $(\mathrm{MW}=990.87)$. $\bigcirc$ : oligosaccharide. 


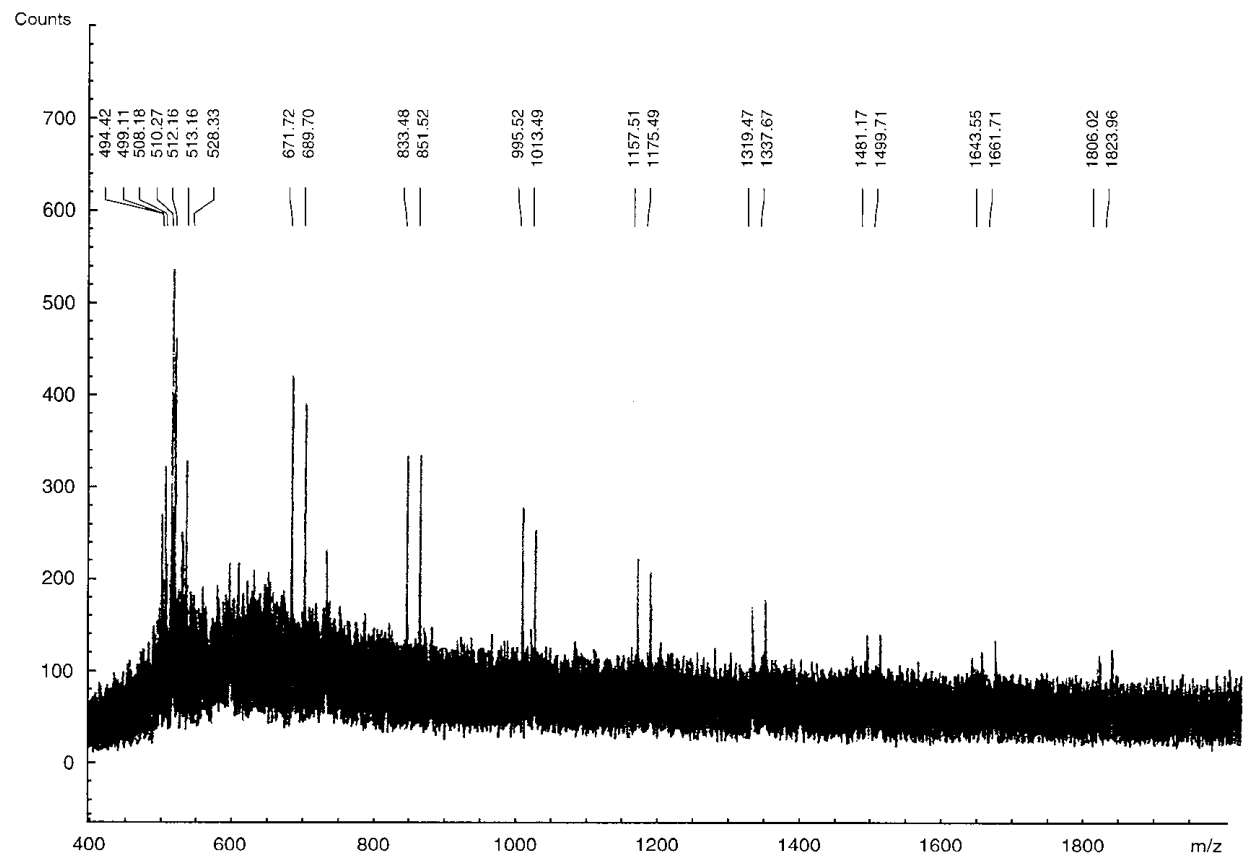

Fig. 2. MALDI-TOF mass spectrum of the garlic oligosaccharide.

The matrix assisted laser-desorption ionization-time of flight (MALDI-TOF) mass spectrum was obtained with BIFLEX III (Bruker) using 2, dihydroxybenzoic acid as a matrix. ${ }^{1} \mathrm{H}$ NMR and ${ }^{13} \mathrm{C}$ NMR spectra were measured on a Varian UNITY INOVA 500 spectrometer at 500 and $125 \mathrm{MHz}$, respectively.

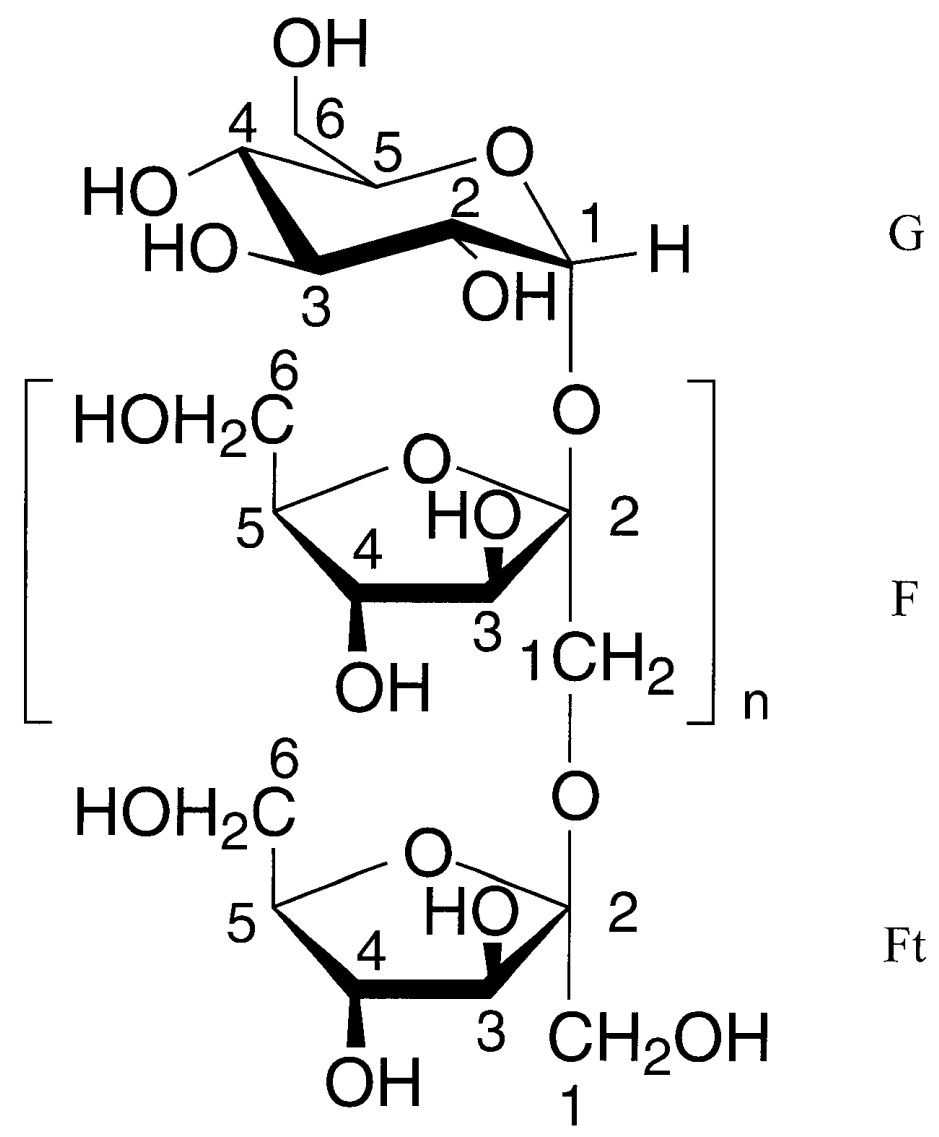

Fig. 3. Speculated structure of the oligosaccharide obtained from garlic. G: glucose, F: fructose $(n=9)$, Ft: fructose terminal. 

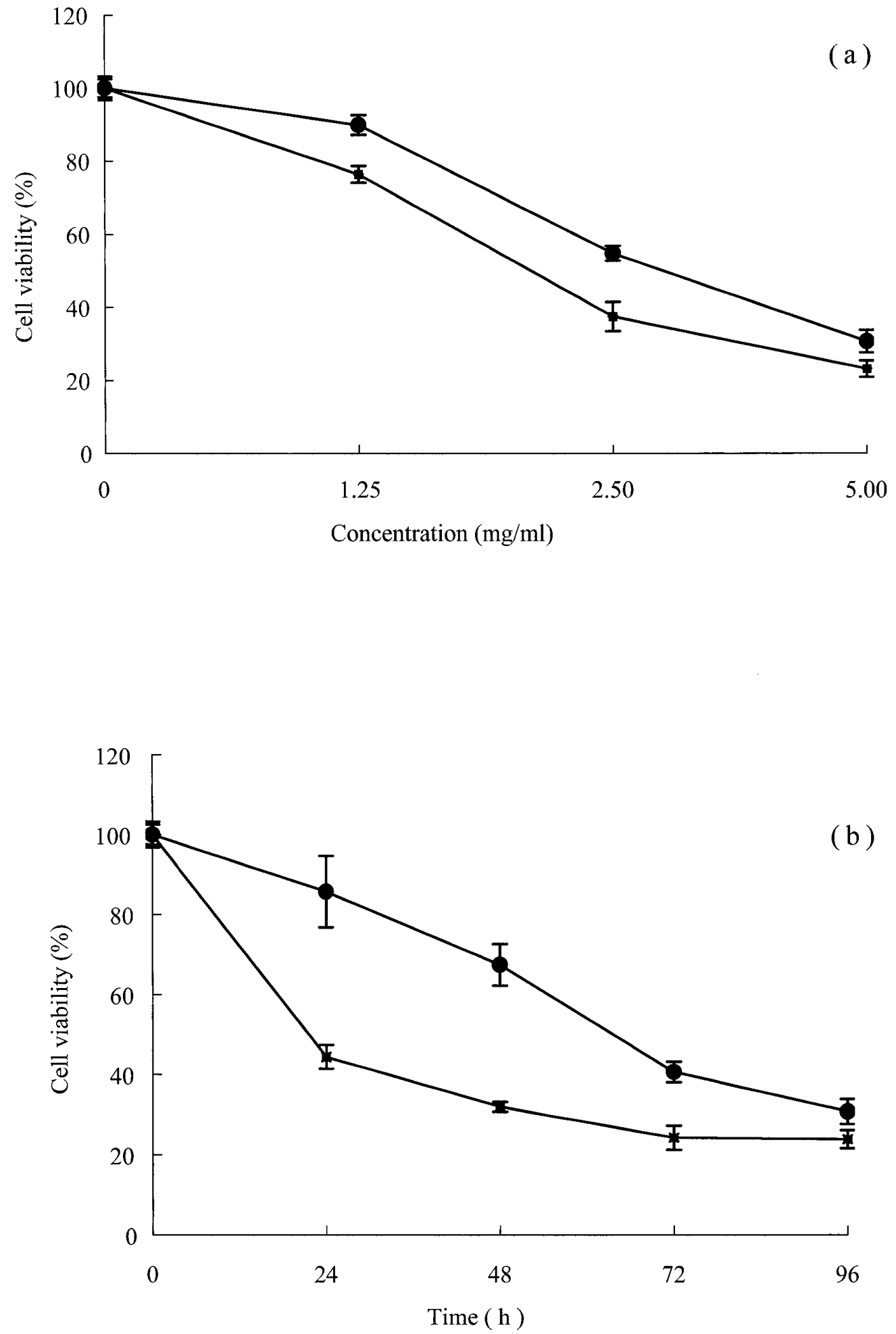

Fig. 4. Dose-dependent effects (a) and time-dependent effects (b) of the garlic oligosaccharide on cell viability. For the dose-dependent effects, cells were treated with different concentrations of oligosaccharide for $96 \mathrm{~h}$ and cell viabilities were determined. For the time-dependent effects, cells were treated with the oligosaccharide $(5 \mathrm{mg} / \mathrm{ml})$ for $24,48,72$ and $96 \mathrm{~h}$ and cell viabilities were determined - : U937, m: WiDr. The cell viability is represented as percent of that of untreated control cells. All data are average \pm S.E. from hexa wells. 
Table 1. Comparison of the NMR data of the oligosaccharide and inulin

\begin{tabular}{|c|c|c|c|c|}
\hline \multirow[b]{2}{*}{ G1 } & \multicolumn{2}{|c|}{${ }^{13} \mathrm{C}(\delta) / \mathrm{ppm}$} & \multicolumn{2}{|c|}{${ }^{1} \mathrm{H}(\delta) / \mathrm{ppm}$} \\
\hline & 94.9 & ( 94.9) & 5.37 & $(5.36)$ \\
\hline $\mathrm{G} 2$ & 73.8 & $(73.6)$ & $\mathrm{a}$ & $(3.46)$ \\
\hline G3 & 74.3 & $75.2(74.2,75.0)$ & & - \\
\hline G4 & 71.8 & $(71.6)$ & $\mathrm{a}$ & $(3.40)$ \\
\hline G5 & 74.3 & $75.2(74.8,75.0)$ & & - \\
\hline G6 & $\mathrm{a}$ & $(62.5)$ & & - \\
\hline $\mathrm{F} 1$ & $62.0 \sim$ & $64.5(63.3)$ & $3.60^{-}$ & $0(3.60 \sim 3.85)$ \\
\hline $\mathrm{F} 2$ & $105.0 \sim$ & $107.0(105.6)$ & & - \\
\hline F3 & $79.0 \sim$ & $82.0(79.3)$ & $4.10^{-}$ & $0(4.18)$ \\
\hline F4 & $77.0 \sim$ & $79.0(76.6)$ & $4.00-$ & $0(4.02)$ \\
\hline F5 & $82.0 \sim$ & $85.0(83.4)$ & $3.80^{-}$ & $0(3.80)$ \\
\hline F6 & $64.5 \sim$ & $66.0(64.5)$ & 3.55 & $5(3.60 \sim 3.85)$ \\
\hline $\mathrm{Ft1}$ & $\mathrm{a}$ & $(62.8)$ & & - \\
\hline $\mathrm{Ft} 2$ & $\mathrm{a}$ & $(106.1)$ & & - \\
\hline $\mathrm{Ft} 3$ & $\mathrm{a}$ & $(79.1)$ & & - \\
\hline Ft4 & $\mathrm{a}$ & $(76.2)$ & & - \\
\hline Ft5 & $\mathrm{a}$ & $(83.4)$ & & - \\
\hline Ft6 & $\mathrm{a}$ & $(64.5)$ & & - \\
\hline
\end{tabular}

In parentheses are shown the chemical of authentic inulin

${ }^{a}$ Not determined due to peak overlapping

- : No signal

Table 2. Inhibitory effect of the oligosaccharide on the growth of Colon-26 cells

\begin{tabular}{lcccc}
\hline Dose (mg/mouse) & $\begin{array}{l}\text { Tumor size } \\
\left(\mathrm{mm}^{3}\right) \\
\text { mean } \pm \text { S.E. }\end{array}$ & $\begin{array}{l}\text { Inhibition } \\
\text { ratio }(\%)\end{array}$ & $\begin{array}{l}\text { Body } \\
\text { weight }(\mathrm{g})\end{array}$ & $\begin{array}{l}\text { Number of } \\
\text { survivors/ } \\
\text { Number tested }\end{array}$ \\
\hline $\begin{array}{l}\text { On the 19th day } \\
0\end{array}$ & $\begin{array}{l}226.2 \pm 85.7 \\
36.4 \pm 10.4\end{array}$ & 0 & 27.3 & $6 / 6$ \\
0.5 & $44.4 \pm 14.6$ & 80 & 26.8 & $6 / 6$ \\
10 & & & 29.0 & $6 / 6$ \\
& & & & \\
On the 22nd day & $307.9 \pm 102.5$ & 0 & 27.5 & $6 / 6$ \\
0 & $32.3 \pm 6.2^{*}$ & 90 & 27.0 & $6 / 6$ \\
0.5 & $55.6 \pm 16.6^{*}$ & 82 & 29.6 & $6 / 6$ \\
10 & & & & \\
\hline
\end{tabular}

Student's $t$ test was used for the statistical analysis of differences

*: Significantly different from control mice at $P<0.05$ 
Table 3. Interferon- $\gamma$ production from human peripheral lymphocytes stimulated with the garlic oligosaccharide

\begin{tabular}{cc}
\hline Oligosaccharide $(\mathrm{mg} / \mathrm{ml})$ & Interferon- $\gamma(\mathrm{IU} / \mathrm{ml})$ \\
\hline 0.0 & $0.21 \pm 0.03$ \\
0.1 & $0.27 \pm 0.02^{*}$ \\
5.0 & $2.13 \pm 0.68^{*}$ \\
\hline
\end{tabular}

Student's $t$ test was used for the statistical analysis of differences

*: Significantly different from control mice at $P<0.05$

$\mathrm{BALB} / \mathrm{cN}$ Sea mice is shown in Table 2. Oral administration of the oligosaccharide resulted in a high inhibitory effect on the growth of Colon- 26 cells. Table 2 shows that more than $80 \%$ of tumor growth inhibitions were observed on the 19th and 22nd days, after oral administrations of oligosaccharide at 0.5 and $10 \mathrm{mg} /$ mouse/every other day. We observed a dose-dependent production of interferon- $\gamma$ in human peripheral lymphocytes treated with the garlic oligosaccharide, as shown in Table 3. We also measured the stimulatory effect of the garlic oligosaccharide on the production of interferon- $\gamma$ in mouse spleen cells (data not shown). Taken together, the oligosaccharide probably binds to cancer cells and inhibits the growth of the cells; furthermore, it may activate the immunological pathways and suppress the growth of tumors in vivo. The above results suggest that the oligosaccharide will provide us with effectiveness in its clinical application.

\section{Acknowledgment}

Financial support provided by Fukuhara Educational Institution is gratefully acknowledged.

\section{References}

1. Norman AG (1941): Chemistry of the carbohydrate and glycoside. Annu Rev Biochem 10 : $65-90$

2. Caragay AB (1992) : Cancer-preventive foods and ingredient. Food Technol $64: 65-68$

3. Wargovich MJ (1987) : Diallyl sulfide, a flavor component of garlic (Allium sativum), inhibits dimethylhydrazine induced colon cancer. Carcinogenesis 8: 487-489

4. Xiao XL, Peng J, Tang SL, Huang YS \& Zhou XT (2006): Diallyl trisulfide induces of human gastric cancer cell line MGC803 through caspase-3 pathway. Al Zheng 25: 1247 $-1251$

5. Miron T, Mironchik M, Mirelman D, Wilchek M \& Rabinkov A (2003) : Inhibition of tumor growth by a novel approach: in situ allicin generation using targeted allinase delivery. Mol Cancer Ther $21: 295-301$

6. Li M, Ciu JR, Ye Y, Min JM, Zhang LH, Wang K, Gares M, Cros J, Wright M \& LeungTack J (2002) : Anti-tumor activity of Z-Ajoene compound purified from garlic: Antimitotic 
and microtubule-interaction properties. Carcinogenesis $23: 573-579$

7. Karasaki Y, Tsukamoto S, Mizusaki K, Sugiura T \& Gotoh S (2001) : A garlic lectin exerted an anti-tumor activity and induced apoptosis in human tumor cells. Food Res Int $34: 7-13$

8. Gallardo S, Cadaba B, del Pozo VD, de Andres BD, Cortegano I, Jurado A, Tramon P, Palomino P \& Lahoz C (1997) : Study of apoptosis in human lymphocytes by toxic substances implicated in toxic oil syndrome. Toxicology $118: 71-82$ 
ニンニクオリゴ糖の精製とその生理的活性

塚本 貞次 ${ }^{1}$, 岡元 孝二 ${ }^{2,3}$, 稲永 順二 ${ }^{4}$, 唐崎 裕治 $5, *$

1 九州女子大学 家政学部

2 九州工業大学 情報工学研究院

3 九州工業大学 生命情報工学科

4 九州大学 先導物質化学研究所

5 產業医科大学 産業保健学部 臨床病態学

要 旨：我々はニンニク鱗茎より糖質を精製した。 この化合物は10 個のフルクトースと $\beta 1-2$ で1 個のグルコースに結合する分子量1800のオリゴ糖であり，植物イヌリンと類似し た構造を持つものであった。このオリゴ糖はヒトのリンパ球性ガン細胞U937 および 大腸ガン細胞WiDrの増殖を抑制した。さらにマウスに経口的投与をした場合におい て、マウスに移植したColon26 ガン細胞の増殖を抑制することがわかった。またヒト 末梢血リンパ球に対してインターフェロン $\gamma$ の産生を増大させることから, ニンニク オリゴ糖はガン細胞に直接結合してガン細胞の增殖を阻害する働きがあると同時に, in vivoの系において免疫的活性を増大させてガン細胞の増殖を抑制する可能性がある ことが示唆された。

キーワード：ニンニク鱗茎, オリゴ糖, 核磁気共鳴, 細胞毒性, 免疫的活性.

J UOEH（産業医大誌）30（2）：147－157（2008）

*現所属：産業医科大学 産業保健学部 看護学科 人間情報科学 